\title{
Does Provision of Smart Services Depend on Cooperation Flexibility, Innovation Flexibility, Innovation Performance or Business Performance in SMEs?
}

\author{
Lucie Kanovska ${ }^{1 *}$, Karel Doubravsky² \\ ${ }^{1}$ Institute of Management, Faculty of Business and Management, Brno University of Technology, 2906/4 Kolejni, 612 00 Brno, \\ Czech Republic \\ 2 Institute of Informatics, Faculty of Business and Management, Brno University of Technology, 2906/4 Kolejni, 61200 Brno, \\ Czech Republic \\ * Corresponding author, e-mail: kanovska@fbm.vutbr.cz
}

Received: 07 February 2020, Accepted: 18 May 2020, Published online: 19 October 2020

\begin{abstract}
Many manufacturers provide a lot of accompanying services to their products. However, not all of them supply smart services, because the move towards these is not easy, especially for SMEs, which often struggle with a lack of money, insufficient digital technologies or unskilled employees. The aim of this paper is to find out if smart service provision depends on cooperation flexibility, innovation flexibility, innovation performance and business performance in SMEs. To fulfil the research aim, quantitative research was carried out among 112 Czech electrotechnical SMEs. The findings show that the higher the rating companies give to working with external customers, the less chance they have of providing smart services. Thus, SMEs who value cooperation flexibility with external customers as less important are more likely to provide smart services. The higher rating companies give to product innovation flexibility, the higher the chance for providing smart services. Thus, we can expect companies who value product innovation flexibility more highly to more likely deliver smart services.
\end{abstract}

Keywords

services in manufacturing, smart services, SMEs, flexibility, performance, electrotechnical manufacturers, Czech Republic

\section{Introduction}

A lot of manufacturers work on the transformation of their tangible products to provision services to satisfy their customers with better complexity. Accompanying services are able to support the company position on the markets and are one of the important sources of competitive advantage. With the growing importance of digital technology, manufacturers are starting to offer smart services to their customers. Digital technologies assist companies to produce and deliver "individual customized" products and services. Hence, customers could be operated on an individual basis, which could improve customer satisfaction and conforming their quality expectations (Sader et al., 2019). The process of integrating services to tangible products is called servitization, and the integration of smart services is called smart servitization.

The issue of smart servitization is specific for SMEs, where the implementation of smart technologies is more demanding due to the often limited financial and personnel capacities. Cooperation between companies is very important today and is gaining in importance. Equally, the importance of flexibility, which is more and more recognized as essential for building a sustainable competitive advantage in product innovation, is increasingly important.

To be able to better understand the situation in manufacturing SMEs in the field of smart service provision, this paper sets out to ascertain if smart service provision depends on innovation and cooperation flexibility and innovation and business performance in electrotechnical SMEs in the Czech Republic. The categorization of SMEs in the research is in accordance with the World Bank's definition of SMEs as enterprises employing between 10-249 employees. The empirical part of the work is focused on electrical engineering companies (CZ-NACE 26 and CZ-NACE 27), which are important representatives of the manufacturing industry and are subcontractors for many other sectors of the economy. In addition, the electrical engineering 
industry is a global industry, which means that on the one hand, many Czech companies can have customers around the world, while on the other hand, competitors can also be global. As a result, it is necessary to constantly focus on research and development, innovate products, respond to customer demand, look for production savings and new trends in the field.

\section{Literature review}

Many opposing terminologies are used for smart services, such as "teleservice" (Borgmeier, 2002), "tele-maintenance" (Garcia et al., 2004), "telematics" (Chatterjee et al., 2001), "e-service" (Rowley, 2006), "e-maintenance" (Levrat et al., 2008) or some variations, combinations or adaptations using the term "remote", such as "RRDM (Remote Repair, Diagnostics and Maintenance)" (Biehl et al., 2004). According to Klein (2017), the term "smart service" has gained popularity more recently. Smart services that offer manufacturing services to their products can also be referred to as accompanying services using smart technologies. For this paper, the term "smart service" is used.

Also, a lot of definitions for smart services were developed over last years. Smart services can be perceived as one of the enablers of servitization (e.g. Grubic and Peppard, 2016; Neu and Brown, 2008) and are the application of specialized competences, through deeds, processes, and performances that are enabled by smart products (Beverungen et al., 2017). "Smart services are technologically-mediated services actively delivered by the provider through accessing a remote asset and exchanging data through built-in control and/or feedback devices" (Klein, 2017). Finally, as Allmendinger and Lombreglia (2005) declare, "Soon, it will not be enough for a company to offer services; it will have to provide smart services.".

Smart services can also offer some valuable benefits for their providers and also for their customers. Smart services are more competitive, offer new sources of revenue, higher margins, and considerable cost savings (Küssel et al., 2000). They provide the opportunity to learn from customers, establishing a basis for research and development, sales or marketing activities (Laine et al., 2010). Smart services allow to detect or early predict machine failures or defective products at early stages and can offer instant root cause analysis as well as instant recommendations of proper remediation (Sader et al., 2019). Porter and Heppelmann (2014) summarize their position: "Smart services offer exponentially expanding opportunities for new functionality, far greater reliability, much higher product utilization, and capabilities that cut across and transcend traditional product boundaries". Allmendinger and Lombreglia (2005) state that companies providing smart services get more than $50 \%$ of revenue and $60 \%$ of margins from services than from product sales.

Digital resources can be a lever for innovation in SMEs (Higón, 2012). They also change the way innovation is managed (Yoo et al., 2009) and make companies more extroverted (Tambe et al., 2012). Digital resources face the traditional spatial constraints of companies which are connected to cooperation in the field of innovation (Deltour et al., 2018). According to Pagani (2013), an increasing interest in business-to-business collaboration can be expected, based on services, which use smart technology and can change traditional business operations and make collaboration a major success factor.

Flexibility has become one of the most useful and necessary tools in today's competitive markets. Flexibility in manufacturing is widely recognized as a critical component for achieving a competitive advantage in the market. Product innovation flexibility is increasingly recognized as essential for building a sustainable competitive advantage in an increasingly turbulent market (Liao et al., 2010).

\section{Methodology}

For a good understanding of the research problem, the qualitative research was undertaken in manufacturing companies. The current research is a follow-up to the earlier research held in 60 manufacturing companies.

The questionnaire consisted of seven parts with suitable questions. Cooperation flexibility was divided into external cooperation flexibility with customers, external cooperation flexibility with suppliers and internal cooperation flexibility. Innovation flexibility was divided into innovation flexibility relating to product and innovation flexibility relating to accompanying services. Also, the questions related to innovation performance and business development were included. The last part of the questionnaire asked for general information about the respondents, including a request about their interest in smart service provision.

The items relating to flexibility were based on Tomášková (2005), Liao and Barnes (2015), Obeidat et al. (2016). The items relating to innovation performance were based on Liao and Barnes (2015) and Obeidat et al. (2016). Performance is defined as system of monitoring individual corporate processes on the way to implement the appropriate changes in organizational culture, systems 
and processes (Milichovský, 2015). Business performance items typically measure the use of marketing performance items (items 1-3) and financial performance items (items 4 and 5). The items relating to provision of smart service were inspired by Bjerke and Johansson (2015), Chaudhuri (2018), Grubic and Peppard (2016).

A Likert scale form from 1 to 5 was used for the questionnaire, where 1 means "No, I don't agree" and 5 means "Yes, I agree". All parts were tested using Cronbach alpha. The level of reliability for external cooperation flexibility for customers was 0.792 , for external cooperation flexibility for suppliers 0.812 , for internal cooperation flexibility 0.814 , for innovation flexibility relating to product 0.832 (product innovation flexibility), for innovation flexibility relating to accompanying services 0.890 , for innovation performance 0.677 and for business performance 0.673 . The levels of reliability were good for all parts of the questionnaire except innovation performance and business performance where the level of reliability is questionable.

Manufacturing SMEs from the Czech Republic participated in the research, especially producers of electric equipment and electronic components. Manufacturers participating in the research comply with the Czech industry classification, namely CZ-NACE 26 (Manufacturer of computer, electronic and optical products) and CZ-NACE 27 (The Production of Electrical Equipment). There are 278 companies in CZ-NACE 26 and 575 companies in CZ-NACE 27 with 10-250 employees according to Czech Statistical Office. Totally there are 853 companies (data are from December 2019).

Small and medium manufacturers were selected from the Amadeus database. Mostly managers and directors were contacted by email and asked to fill out a questionnaire, which was web-based. Incomplete questionnaires were discarded. The data was collected from July to October 2019. The total number of SMEs from CZ-NACE 26 and from CZ-NACE 27 in the Amadeus database was 730 (254 SMEs from CZ-NACE 26 and 476 SMEs from CZ-NACE 27). All 730 companies were contacted, but 22 emails were sent back immediately. These companies have already ceased to exist or are in liquidation or contact emails were missing and the companies were no longer traceable. In total, 112 fully completed questionnaires were received back. The questionnaire return rate corresponds to $15.8 \%$. The data analysis was done by the software package SPSS, Version 17.

The paper is focused on smart service provision and on cooperation flexibility and innovation flexibility in manufacturing SMEs. The following research question was proposed RQ: Does Provision of Smart Services depend on cooperation flexibility, innovation flexibility, innovation performance and business performance in SMEs?

Logistic regression was chosen to fulfill the aim of the paper. Logistic regression is used to create a model where the dependent variable is a categorical variable (smart service provision). Independent variables (where it is possible to monitor whether they have an influence on the dependent variable) can be both metric and categorical variables.

\section{Findings}

The Research Question used binary logistic regression to describe the dependence of smart services provision on quantitative research areas. The dependent variable is dichotomous (Yes, No). Independent variables are metric variables:

- collaborative flexibility/external - customers,

- collaborative flexibility/external - suppliers,

- collaborative flexibility/internal, innovation flexibility by product,

- innovation flexibility by accompanying services,

- innovation performance and business performance.

The following Table 1 shows the significance of independent variables measured by Wald's statistics.

First of all, the view was focused on a constant that has no logical interpretation in the model. Based on the $p$-value of the significance test of the constant, which is higher than the selected significance level of 0.05 , the constant is statistically insignificant ( $t$ doesn't have information value for this mode). The model is recreated without a constant. Thus, a new reduced model is calculated, see Table 2.

Table 1 Significance of variables in the model

\begin{tabular}{|c|c|c|c|c|c|c|}
\hline & B & S.E. & Wald & df & $p$-value & $\operatorname{Exp}(B)$ \\
\hline $\begin{array}{l}\text { External- } \\
\text { customers }\end{array}$ & -1.558 & 0.590 & 6.987 & 1 & 0.008 & 0.211 \\
\hline $\begin{array}{l}\text { External- } \\
\text { suppliers }\end{array}$ & 0.261 & 0.330 & 0.623 & 1 & 0.430 & 1.298 \\
\hline Internal & 0.675 & 0.441 & 2.341 & 1 & 0.126 & 1.964 \\
\hline $\begin{array}{l}\text { Flexibility } \\
\text { by product }\end{array}$ & 0.801 & 0.486 & 2.719 & 1 & 0.099 & 2.228 \\
\hline $\begin{array}{l}\text { Flexibility } \\
\text { by accomp. } \\
\text { services }\end{array}$ & 0.296 & 0.424 & 0.488 & 1 & 0.485 & 1.345 \\
\hline $\begin{array}{l}\text { Innovation } \\
\text { Performance }\end{array}$ & -0.416 & 0.380 & 1.200 & 1 & 0.273 & 0.660 \\
\hline $\begin{array}{l}\text { Business } \\
\text { Performance }\end{array}$ & 0.902 & 0.474 & 3.630 & 1 & 0.057 & 2.466 \\
\hline Constant & -2.726 & 1.591 & 2.937 & 1 & 0.087 & 0.065 \\
\hline
\end{tabular}


Table 2 Significance of variables in the model

\begin{tabular}{|c|c|c|c|c|c|c|}
\hline & $B$ & S.E. & Wald & $\mathrm{df}$ & $p$-value & $\operatorname{Exp}(B)$ \\
\hline $\begin{array}{l}\text { External- } \\
\text { customers }\end{array}$ & -1.849 & 0.568 & 10.580 & 1 & 0.001 & 0.157 \\
\hline $\begin{array}{l}\text { External- } \\
\text { suppliers }\end{array}$ & 0.149 & 0.314 & 0.227 & 1 & 0.634 & 1.161 \\
\hline Internal & 0.620 & 0.428 & 2.102 & 1 & 0.147 & 1.860 \\
\hline $\begin{array}{l}\text { Flexibility } \\
\text { by product }\end{array}$ & 0.904 & 0.474 & 3.643 & 1 & 0.056 & 2.470 \\
\hline $\begin{array}{l}\text { Flexibility } \\
\text { by accomp. } \\
\text { services }\end{array}$ & 0.219 & 0.407 & 0.291 & 1 & 0.590 & 1.245 \\
\hline $\begin{array}{l}\text { Innovation } \\
\text { Performance }\end{array}$ & -0.605 & 0.360 & 2.835 & 1 & 0.092 & 0.546 \\
\hline $\begin{array}{l}\text { Business } \\
\text { Performance }\end{array}$ & 0.822 & 0.460 & 3.191 & 1 & 0.074 & 2.275 \\
\hline
\end{tabular}

According to the $p$-values of the significance tests of the individual regression coefficients, it can be seen in Table 2 that the only variable having a significant impact on smart services provision is flexibility in the field of cooperation/ external/customers $(p$-value $<0.05)$. Higher values of $p$-values indicate there are high correlations between independent variables (a multicollinearity problem). For this reason, the dependence between the independent variables is determined by a correlation matrix. There are strong dependences (greater than 0.9) between variables innovation flexibility by accompanying services:

- collaborative flexibility/external-customers,

- collaborative flexibility/external-suppliers,

- collaborative flexibility/external - customers,

- collaborative flexibility/internal and innovation flexibility by product,

- innovation performance,

- innovation flexibility by product, business performance

- innovation flexibility by product.

First of all, the view is focused on the dependence of innovation flexibility by accompanying services:

- collaborative flexibility/external

- suppliers on collaborative flexibility/Externalcustomers.

New reduced models are calculated by removing the relevant variables or pairs of variables from the original model. These reduced models are compared $\left(R^{2}\right.$ is taken as a criterion). The best model is presented in Table 3 .

The problem of the existence of a strong dependence of collaborative flexibility/internal, innovation performance, business performance on innovation flexibility
Table 3 Significance of variables in the model

\begin{tabular}{lcccccc}
\hline & $B$ & S.E. & Wald & df & $p$-value & $\operatorname{Exp}(B)$ \\
\hline $\begin{array}{l}\text { External- } \\
\text { customers }\end{array}$ & -1.781 & 0.517 & 11.883 & 1 & 0.001 & 0.168 \\
$\begin{array}{l}\text { Internal } \\
\begin{array}{l}\text { Flexibility } \\
\text { by product }\end{array}\end{array}$ & 0.699 & 0.414 & 2.844 & 1 & 0.092 & 2.012 \\
$\begin{array}{l}\text { Innovation } \\
\text { Performance }\end{array}$ & -0.566 & 0.354 & 2.557 & 1 & 0.110 & 0.568 \\
$\begin{array}{l}\text { Business } \\
\text { Performance }\end{array}$ & 0.843 & 0.461 & 3.352 & 1 & 0.067 & 2.324 \\
\hline
\end{tabular}

by product is solved in the same way. New reduced models are calculated by removing the relevant variables or pairs of variables or triplet of variables from the original model. These reduced models are compared $\left(R^{2}\right.$ is taken as a criterion). The best model is presented in Table 4.

Table 4 shows two variables that do not correlate significantly. Thus, the model describing the provision of smart services can only be described as shown in Table 4.

Both variables in this model are statistically significant ( $p$-value $<0.05)$. According to the last column $\operatorname{Exp}(B)$, which is the exposed coefficient or chance, the provision of smart services can be interpreted by changing the predictor by one.

The higher the rating companies give to working with external customers, the less chance they have of providing smart services. Thus, for companies evaluating worse cooperation with external customers, we are more likely to provide smart services. The higher the rating companies give innovation to the product, the higher the chance they have of providing smart services. Thus, to companies evaluating product innovation, we can be more likely to deliver smart services.

Looking at the results in terms of whether the business score in each region affects smart services provision, it can be said that the chances of providing smart services for an enterprise evaluating cooperation flexibility/external/customers average 2, is 0.439 times higher than the company that evaluates flexibility in the field of collaboration/external/customers on average 1 . So it can be said that the increasing evaluation of flexibility in the field of

Table 4 Significance of variables in the model

\begin{tabular}{lcccccc}
\hline & $B$ & S.E. & Wald & df & $p$-value & $\operatorname{Exp}(B)$ \\
\hline $\begin{array}{l}\text { External- } \\
\text { customers }\end{array}$ & -0.824 & 0.257 & 10.267 & 1 & 0.001 & 0.439 \\
$\begin{array}{l}\text { Flexibility } \\
\text { by product }\end{array}$ & 0.970 & 0.308 & 9.958 & 1 & 0.002 & 2.639 \\
\hline
\end{tabular}


cooperation flexibility/external/customers reduces the chances of providing smart services. It can also be seen from the other side, which means that a company evaluating flexibility in external cooperation - customers on average 1, has 2.278 times higher chances of not providing smart services than an agency evaluating cooperation flexibility in external cooperation - customers on average 2 . The chances of providing smart services for a manufacture that evaluates innovation flexibility for a product average of 2 , are 2.639 times higher than a company that evaluates innovation flexibility for a product average of 1 .

\section{Discussion}

To fulfill the research question stated above, logistic regression creates a model describing the impact of some areas on smart service provision. The quantitative research carried out confirmed only two areas. The general model for seven parts looks like this:

$$
\begin{aligned}
& \log \frac{\pi(x)}{1-\pi(x)}=\alpha+\beta_{1} x_{1}+\beta_{2} x_{2}+\beta_{3} x_{3}+\beta_{4} x_{4}+\beta_{5} x_{5} \\
& +\beta_{6} x_{6}+\beta_{7} x_{7} .
\end{aligned}
$$

The resulting model looks like this:

$$
\log \frac{\pi(x)}{1-\pi(x)}=\beta_{1} x_{1}+\beta_{2} x_{2},
$$

specifically:

$$
\log \frac{\pi(x)}{1-\pi(x)}=-0.824 x_{1}+0.97 x_{2} .
$$

Interpretation is not via the graph but table and chances, see Table 4. The higher the rating companies give to working with external customers, the less chance they have of providing smart services. Thus, for companies evaluating worse cooperation with external customers, they are more likely to provide smart services. The higher the rating companies give to innovation of the product, the higher the chance they are of providing smart services. Thus, for companies evaluating

\section{References}

Allmendinger, G., Lombreglia, R. (2005) "Four Strategies for the Age of Smart Services", Harvard Business Review, 83(10), Article Number: 131. [online] Available at: https://harborresearch.com/ wp-content/uploads/sites/8/2018/09/Harvard-Business-Review_ Four-Strategies-for-Smart-Services_Allmendinger-Lombreglia.pdf [Accessed: 10 July 2019]

Beverungen, D., Matzner, M., Janiesch, C. (2017) "Information systems for smart services", Information Systems and e-Business Management, 15(4), pp. 781-787. https://oi.org/10.1007/s10257-017-0365-8 product innovation, we can be more likely to deliver smart services. This finding is in line with Biehl (2017) that smart services "raised high expectations of its potential" and are widely used to describe the company's innovation.

If we want to answer the research question, "Does Provision of Smart Services depend on cooperation flexibility, innovation flexibility, innovation performance and business performance in SMEs?", we have to say that provision of smart services depends only on cooperation flexibility/external/customers and on innovation flexibility relating to product. Only two parts from seven possible affect the smart service provision significantly.

\section{Conclusion}

The findings of the research show that the provision of smart services depends on cooperation flexibility/external/customers and innovation flexibility relating to product. Both variables from seven possible in the above-mentioned model are statistically significant $(p<0.05)$. The provision of smart services can be interpreted by changing the predictor by one. The higher the rating companies give to working with external customers, the less chance they have of providing smart services. The higher the rating companies give to innovation of the product, the higher the chance they have of providing smart services.

It would certainly be interesting to continue research in other industries and then be able to compare the provision of smart services. The article limit may be in a sample of manufacturers, targeting only one industry and respondents within one country. Therefore, further research will be directed to other industries to identify the most comprehensive view of the provision of smart services to industrial manufacturers.

\section{Acknowledgement}

Eva Tomaskova contributed in the research, which was held in 112 electrotechnical SMEs companies in the Czech Republic in 2019.

Biehl, M., Prater, E., McIntyre, J. R. (2004) "Remote repair, diagnostics, and maintenance", Communications of the ACM, 47(11), pp. $100-106$ https://doi.org/10.1145/1029496.1029501

Biehl, S. (2017) "Design Guidelines for Smart Services: A Strategiclogic Perspective on Seeking Competitive Advantage with Digitized Servitization Strategies", Doctoral dissertation, University of St. Gallen. 
Bjerke, L., Johansson, S. (2015) "Patterns of innovation and collaboration in small and large firms", The Annals of Regional Science, 55(1), pp. 221-247.

https://doi.org/10.1007/s00168-015-0712-y

Borgmeier, A. (2002) "Teleservice und die Neue Institutionenökonomie" (Teleservices in mechanical and plant engineering: applications and design recommendations), In: Teleservice im Maschinenund Anlagenbau, Deutscher Universitätsverlag, Wiesbanden, Germany, pp. 115-147. (in German) https://doi.org/10.1007/978-3-322-81064-9_4

Chatterjee, A., Greenberg, J., Jones, M., Kaas, H. W., Wojcik, P. (2001) "Telematics: Decision Time for Detroit", Business Strategy Review, 12(2), pp. 21-38. https://doi.org/10.1111/1467-8616.00172

Chaudhuri, A. (2018) "Internet of Things, for Things, and by Things", Auerbach Publications, New York, NY, USA. https://doi.org/10.1201/9781315200644

Deltour, F., Le Gall, S., Lethiais, V. (2018) "The spatiality of SMEs' cooperation for innovation in the digital age: a mixed method study", In: 4th Geography of Innovation Conference (GeoInno 2018), Barcelona, Spain, pp. 1-14.

Garcia, E., Guyennet, H., Lapayre, J. C., Zerhouni, N. (2004) "A new industrial cooperative tele-maintenance platform", Computers \& Industrial Engineering, 46(4), pp. 851-864. https://doi.org/10.1016/j.cie.2004.05.019

Grubic, T., Peppard, J. (2016) "Servitized manufacturing firms competing through remote monitoring technology: An exploratory study", Journal of Manufacturing Technology Management, 27(2), pp. 154-184.

https://doi.org/10.1108/JMTM-05-2014-0061

Higón, D. A. (2012) "The impact of ICT on innovation activities: Evidence for UK SMEs", International Small Business Journal: Researching Entrepreneurship, 30(6), pp. 684-699. https://doi.org/10.1177/0266242610374484

Klein, M. M. (2017) "Design rules for smart services", Doctoral dissertation, University of St. Gallen. [online] Available at: http:// verdi.unisg.ch/www/edis.nsf/SysLkpByIdentifier/4607/\%24FILE/ Dis4607.pdf [Accessed: 12 November 2018]

Küssel, R., Liestmann, V., Spiess, M., Stich, V. (2000) "'TeleService" a customer-oriented and efficient service?", Journal of Materials Processing Technology, 107(1-3), pp. 363-371. https://doi.org/10.1016/S0924-0136(00)00727-5

Laine, T., Paranko, J., Suomala, P. (2010) "Downstream shift at a machinery manufacturer: the case of the remote technologies", Management Research Review, 33(10), pp. 980-993. https://doi.org/10.1108/01409171011083987

Levrat, E., Iung, B., Crespo Marquez, A. (2008) "E-maintenance: review and conceptual framework", Production Planning \& Control, 19(4), pp. 408-429.

https://doi.org/10.1080/09537280802062571
Liao, Y., Barnes, J. (2015) "Knowledge acquisition and product innovation flexibility in SMEs", Business Process Management Journal, 21(6), pp. 1257-1278

https://doi.org/10.1108/BPMJ-05-2014-0039

Liao, Y., Hong, P., Rao, S. S. (2010) "Supply Management, Supply Flexibility and Performance Outcomes: An Empirical Investigation of Manufacturing Firms", Journal of Supply Chain Management, 46(3), pp. 6-22. https://doi.org/10.1111/j.1745-493X.2010.03195.x

Milichovský, F. (2015) "Financial Key Performance Indicators in Engineering Companies", Periodica Polytechnica Social and Management Sciences, 23(1), pp. 60-67. https://doi.org/10.3311/PPso.7810

Neu, W. A., Brown, S. W. (2008) "Manufacturers forming successful complex business services: Designing an organization to fit the market", International Journal of Service Industry Management, 19(2), pp. 232-251. https://doi.org/10.1108/09564230810869757

Obeidat, B. Y., Al-Suradi, M. M., Masa'deh, R., Tarhini, A. (2016) "The impact of knowledge management on innovation: An empirical study on Jordanian consultancy firms", Management Research Review, 39(10), pp. 1214-1238. https://doi.org/10.1108/MRR-09-2015-0214

Pagani, M. (2013) "Digital Business Strategy and Value Creation: Framing the Dynamic Cycle of Control Points", MIS Quarterly, 37(2), pp. 617-632. [online] Available at: https://www.jstor.org/ stable/43825925?seq=1 [Accessed: 05 July 2019]

Porter, M. E., Heppelmann, J. E. (2014) "How Smart, Connected Products Are Transforming Competition", Harvard Business Review, 92(11), pp. 64-88. [online] Available at: https://www.gospi.fr/ IMG/pdf/porter-2014-hbr_how-smart-connected-products-aretransforming-competitionhbr-2014.pdf [Accessed: 10 July 2019]

Rowley, J. (2006) "An analysis of the e-service literature: towards a research agenda", Internet Research, 16(3), pp. 339-359. https://doi.org/10.1108/10662240610673736

Sader, S., Husti, I., Daróczi, M. (2019) "Industry 4.0 as a Key Enabler toward Successful Implementation of Total Quality Management Practices", Periodica Polytechnica Social and Management Sciences, 27(2), pp. 131-140. https://doi.org/10.3311/PPso.12675

Tambe, P., Hitt, L. M., Brynjolfsson, E. (2012) "The Extroverted Firm: How External Information Practices Affect Innovation and Productivity", Management Science, 58(5), pp. 843-859. https://doi.org/10.1287/mnsc. 1110.1446

Tomášková, E. (2005) "Měření tržní orientace a její vliv na podnikový výkon" (Measuring of market orientation and its influence on business performance), Doctoral dissertation, Brno University of Technology. (in Czech)

Yoo, Y., Boland, R. J., Lyytinen, K., Majchrzak, A. (2009) "Call for Papers-Special Issue: Organizing for Innovation in the Digitized World", Organization Science, 20(1), pp. 278-279. https://doi.org/10.1287/orsc.1080.0416 